\title{
Goenrich Basic Technique Model with Playing Approach for a Beginner Tennis Player
}

\author{
Nurkadri \\ Faculty of Sport Science \\ Universitas Negeri Medan \\ Medan, Indonesia \\ nurkadri@unimed.ac.id
}

\begin{abstract}
- this study was conducted to develop a basic technique model with playing approach for a beginner tennis player, It adopted model development by Borg \& Gall through four stages: 1) identification and requirement analysis 2) design development and draft model 3) test phase (trial and expert review) 4) model implementation. The sample for this study was collected from beginner tennis players in Medan, North Sumatra. Data collection employed observation, questionnaires, documentation and tests. Data analysis were descriptive, qualitative and quantitative. The result of this study found Goenrich basic technique model with playing approach for a beginner tennis player through 28 forms of basic tennis techniques ( 7 forms basic forehand, 7 forms basic backhand, 7 forms basic volley, 7 forms service).
\end{abstract}

\section{Keywords—goenrich model, playing approach}

\section{INTRODUCTION}

Based on demand analysis of this study, researchers observed that the basic tennis technique focused solely on how to hit the ball with a racket and swing a racket, regardless of playing approach method of the playing approach as supporting a good and correct basic techniques of tennis. Moreover, the exercise is done only with the memory of the trainer he ever did when being an athlete. Worse yet, the basic skills training that he did not have a clear exercise program. This certainly gives a bad impact on the ability of tennis players to create reliable players. Based on observations by researchers in May and June 2015 during Inter-Institutional and Junior Open matches, some randomly picked tennis players, a defect ratio was obtained in the basic technique of hitting the tennis ball described in the chart below :

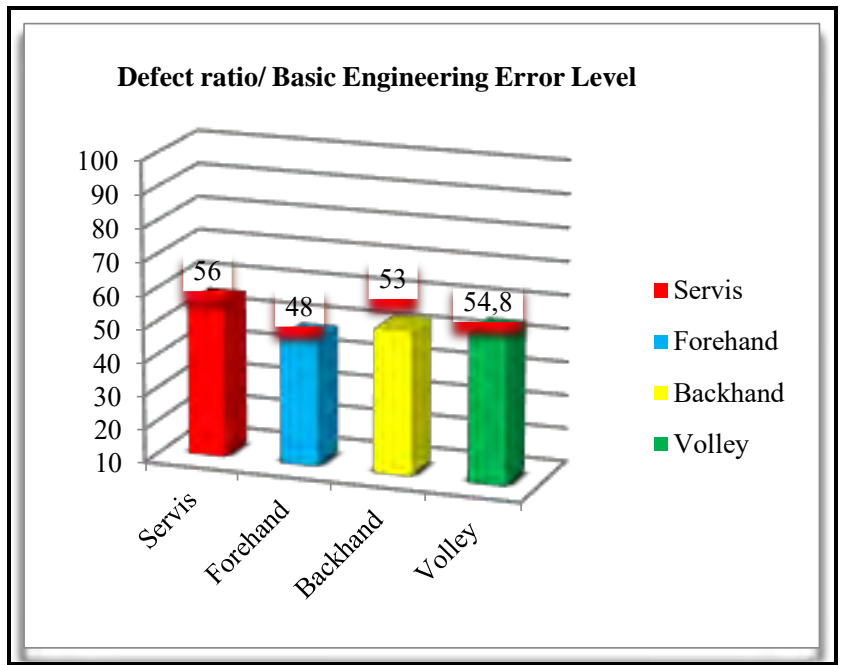

Fig. 1. Diagram of the researchers observation of serve blows, forehand backhand and volley. (Source: Compiled by Researcher).

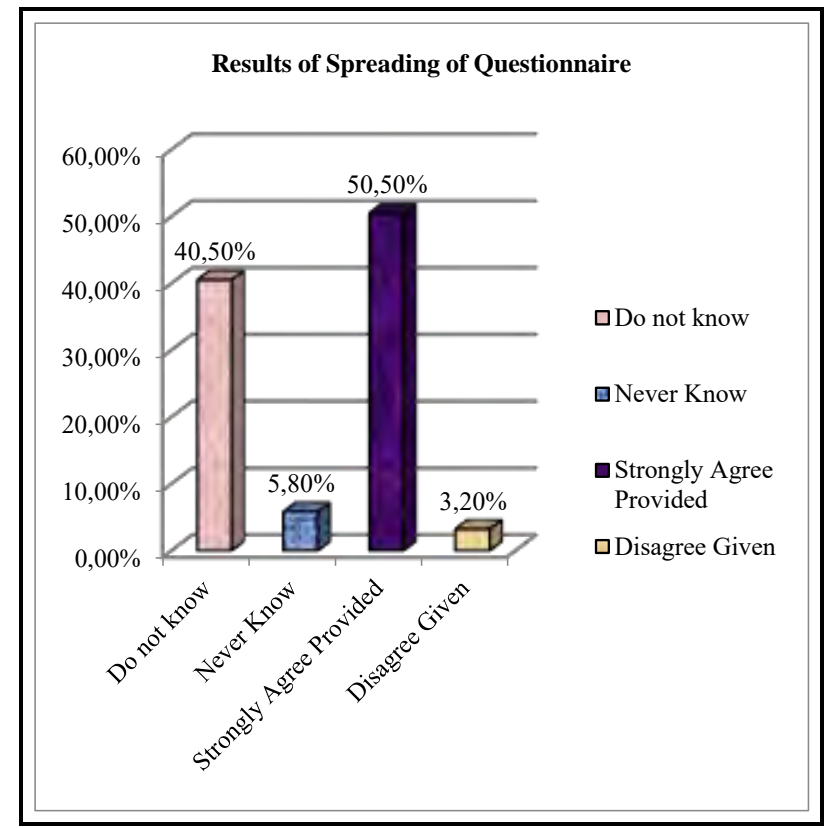

Fig. 2. Observation Diagram of Researchers on the Distribution of Requirement Analysis Questionnaire. (Source: Compiled by Researcher) 
In connection with the requirement analysis, then to perform the process of basic tennis exercise techniques, selected models of exercise with proper play approach and easy to apply to Beginner players, so that various basic motion skills as well as movement coordination can be mastered properly and correctly. Based on the description of background of the problem, the research focuses on Model Development of Basic Technique Exercise of Tennis Based on Playing Approach To Increase The ability of forehand, backhand, serve, and volleyball basic tennis court on beginner players who are in the tennis club in Medan Province of North Sumatra.

\section{LITERATURE RESEARCH}

Development originated from the word 'develop' which means to be more perfect. Then the word gets affixes to be "development" which means process, way, or action to develop. So development is an effort made to achieve the desired goal to be more perfect than ever [1]. Development means deepening and extending existing knowledge [2]. In Scientific Writing Guideline of State University of Malang, development is an activity that produces design or product that can be used to solve actual problems [3]. Furthermore, research and development have a goal not to formulate or test the theory but to develop effective results to be utilized in schools or other institutions [4].

Development models that are often used in developing an instructional system design are: 1) Jolly and Bolitho Development Model 2) Sugiyono development model 3) Dick and Carey Development Model 4) Addie Model 5) Instructional Development Model (MPI) 6) Gagne and Briggs Model 7) JE Model Kemp 8) Bela H.Banathy Model 9) Borg and Gall Development Model.

Essentially, a model is a visualization that is applied as a guide in doing activities and describes the existence of a pattern of thinking. A model usually describes the whole concept of mutual attachment, which means the model can also be seen as an attempt and to concretize a theory as well as an analogue and represent the variables contained in the theory [5]. Furthermore, "A model is an abstraction of reality; a simplified representation of a real-worid phenomenon" [6]. The purpose of the definition is to explain a model being a representation of some phenomena that exist in the real world and "that the model is a representation of reality presented with a degree of structure and sequence" [7].

Therefore, determining a model design for developing a training program depends on the consideration of model to be used or selected. So the model in this study chooses or uses models to improve the basic technical skills in tennis games. In this case, the model is more specific to the use of forehand, backhand, serve, and basic tennis for beginner players in tennis clubs located in Medan North Sumatra.

Basically a research seeks to find answers to a problem, while development seeks to apply findings or theories to a problem. Research and development is often known as Research and Development (R \& D) or in terms of research based development. Research and development is a research that aims to generate products, design, and process. Research and development is not a research to find a theory, but research that aims to produce and develop a product [8]. Research and development in education/ training is defined as follows: "Educational Research and Development (Educational R \& D) is an industry-based development model in which the findings of the research are used to design new products and procedures, which are systematically field-tested, evaluated and refined until they meet specified criteria of effectiveness, quality, or similar standards."[9]

The research that will be developed is GOENRICH BASIC model (the basic tennis technique skills training model for beginners). The model used is Borg and Gall's Research \& Development (R \& D) consisting of ten steps.

Furthermore "exercise is a systematic process with the aim of improving the athlete's physical fitness by performing certain activities"[10]. Then "states exercise is a process of giving patterns, rules and understanding to learn in good condition [11]. "States practice is a process or period of time that lasts for several years until the sportsman or sportswoman reaches the highest performance standard"[12]. Furthermore, it is explained that "training is a collection of understanding of all efforts in the process of improving achievement including all efforts to maintain achievement"[13]. This explains that training is a systematic exercise, process or activity carried out in a repetitive manner that always seeks to increase the burden of practice in a progressive and individual way to achieve the desired goals.

The skill mastery level can be divided into four levels which are: Beginner level, intermediate, advanced and higly skilled. The limits of mastery of the skills of each level are not clearly visible. The limit is only approximate. However, the estimate can be done well if done by someone skilled in terms of skill movement. For example, a good football coach will be able to assess every athlete to be at the level of skill at which the athlete is supposed to be located in [14].

From some opinions above, the author took the conclusion of this development research using a beginner player. Beginner here is the level of mastery of motion skills in sports at the Beginner level. In this case, a beginner is a player who is just beginning to practice tennis. This beginner player is a player who has never done anything, understood or mastered the sport of tennis.

Goenrich model is inspired by the merging of the names of both parents namely the father named 'Mount' and mother named 'Ribut'. Adviced and directed by the promoter and copromoter for the development of this model, there should be a new name for the basic engineering model that will be developed. While holding a meeting at Gajebo Post Graduate University Negeri Jakarta with Feby Kurniawan, Budiman Agung (Ucup), Bayu Hardiono (Badunk), Anak Agung Putra Yasa (Ajunk) and Hendra, researchers at that time immediately remember the names of both parents. The change of Goenri to Goenrich comes after the researchers met and discussed with one of the students when the researcher first trained the field tennis in Medan. The students of the researcher gave suggestions or inputs of Goenri's words to add the $\mathrm{CH}$ in the back (Goenri-ch) to be cool and make it seem like the German language. In the scheme of thinking of the development of Goenrich basic technique, an exercise 
model on the beginner with a play approach was presented in the following figure.

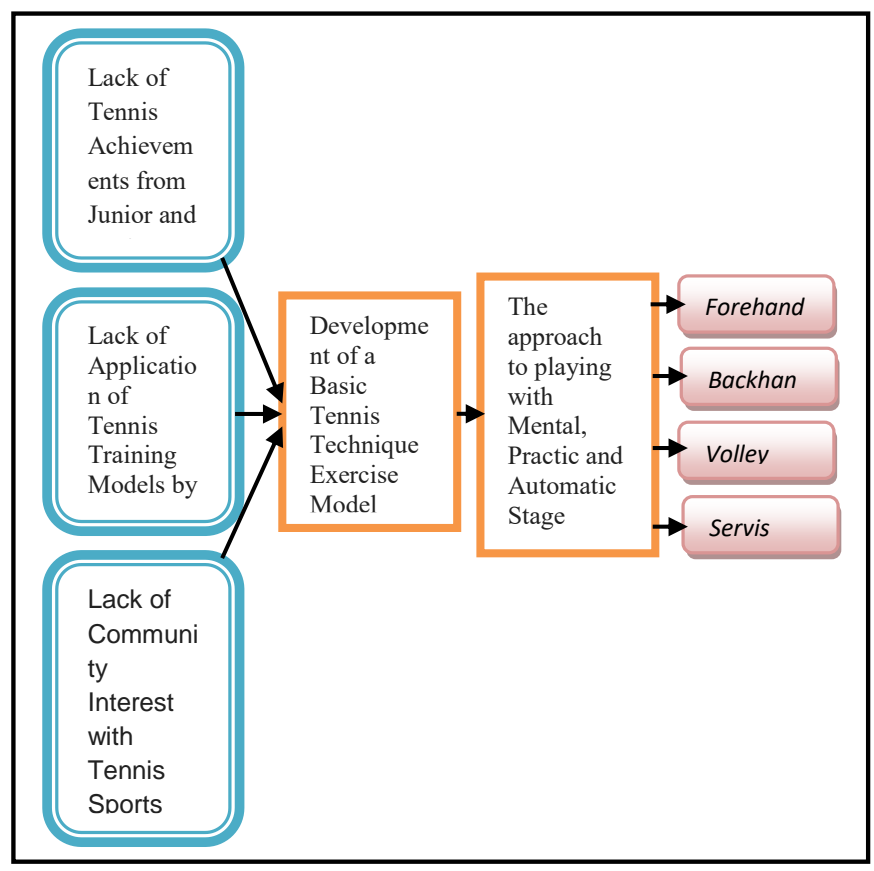

Fig. 3. Thinking Flow Research and Development of Basic Techniques Goenrich On Beginner Tennis Players (Source: Compiled by Researchers)

Read more on the chart below about the Goenrich model description that will be developed in this study as follows:

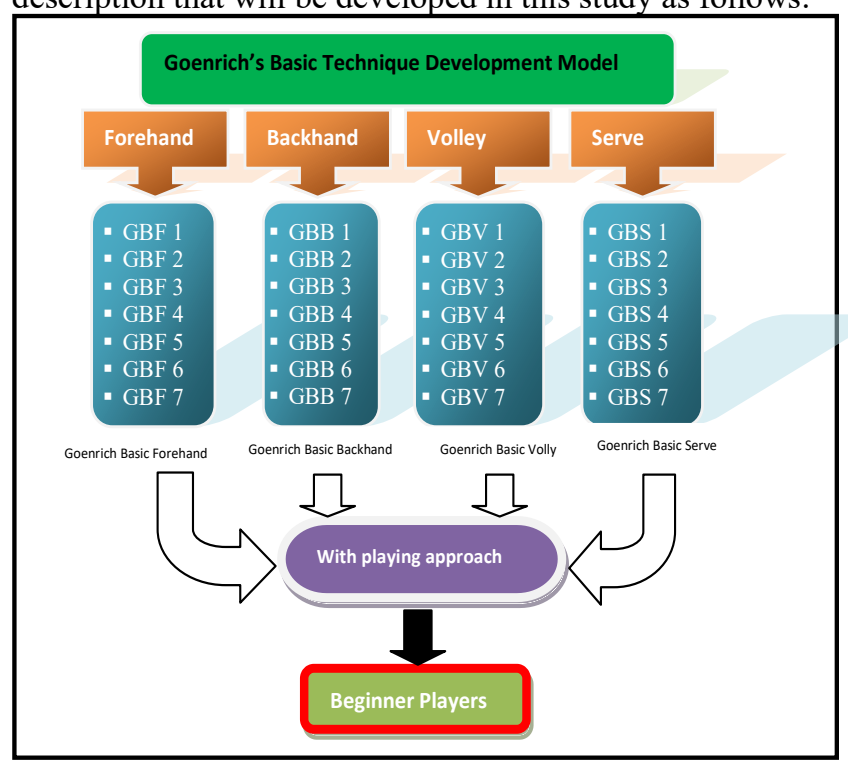

Fig. 4. The Design of Basic Technique Development Model Goenrich (Source: Compiled by Researcher).

Based on the classification of technical exercises proposed by Rusdianto \& Setyo Bidiwanto beforehand, it can be understood that in doing every basic technique exercise, it must be through several stages, ranging from easy, moderate to high difficulty level. Referring from this theory, in this research it will be done by a process in such a way that in basic technique practice Goenrich on beginner tennis players will be applied to the stages as above.
In the easy-to-see stage of basic Goenrich; Basic Forehand 1-3 technical exercises, Goenrich Basic Backhand 1-3, Goenrich Basic Volley 1-3, and Goenrich Basic Serve 1-3. As for the stage that is being seen in the basic techniques of Goenrich Basic Forehand 4-5, Goenrich Basic Backhand 4-5, Goenrich Basic Volley 4-5, and Goenrich Basic Serve 4-5. For a high or difficult stage seen in basic Goenrich Basic Forehand 6-7 technical exercises, Goenrich Basic Backhand 6-7, Goenrich Basic Volley 6-7, and Goenrich Basic Serve 6-7.

\section{RESEARCH METHODS}

Specific formulated objectives research to create a product model of Goenrich basic exercise techniques in sports tennis with a play approach for the beginner. Testing the effectiveness of basic tennis skills training models and gaining empirical data on the effectiveness, efficiency and attractiveness of basic Goenrich technique development exercises in tennis for beginners is also done.

The ultimate goal of this development research is to produce a book or module product containing the Basic Goenrich exercise model in Tennis sport which benefits trainers, lecturers and beginner players in particular.

This research was conducted for 9 months (November 2015 - August 2016). Users of the model being targeted in the research of developing the basic technique training model are players who are new to the sport of tennis in Medan North Sumatra.

Beginner players are very important in perfecting the technique. If the gold age fails to learn / practice, beginner players do not have perfect techniques, the players need hard work and a long time to be able to perfect technique in the future [15].

All children grow and their movement develops as a change in motion behavior that reflects the interaction between a mature organism and its environment. Motion behavior requires functional coordination between muscles, cognitive, affective, and psychomotor functions [16].

Psychomotor ability refers to the ability to coordinate all body parts of the player with the brain functioning in sync to achieve physical goals. An important foundation for building good psychomotor abilities in beginner players is the improvement of basic techniques of beginner players' movements, where brain function and motor engineering development go hand in hand at a very early age or golden age.

This research focuses on developing a model of engineering practice. The approach and method used in this research is mixed. The research combines qualitative and quantitative methods. While the research method used in this research is a method developed by researchers by adopting research and development [17], with consideration to development research stage consisting of 10 stages in 4 stages depicted below. 


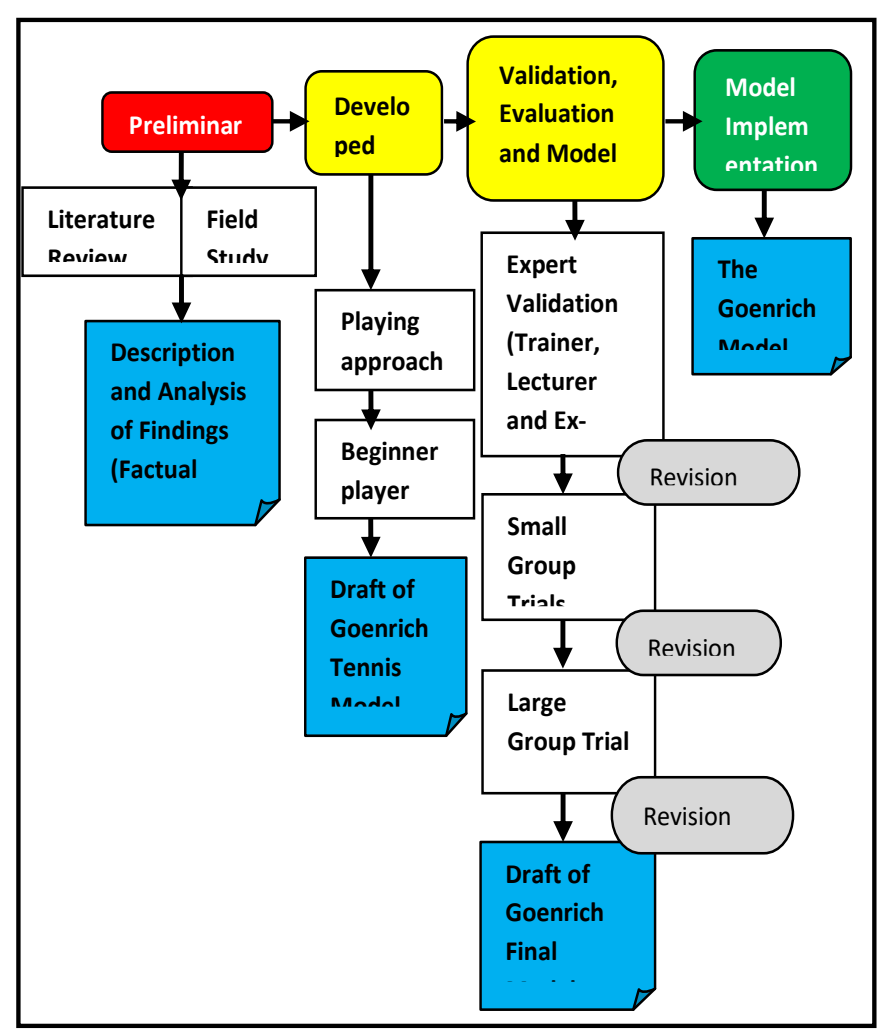

Fig. 5. Steps of Use of R \& D Methods According to Researchers, was adopted from Borg and Gall. (Source: Compiled by Researcher)

The steps undertaken in the effectiveness test in this study are as follows: (1) assignment of beginner players as research subjects of 80 players (2) conducting pre-test exercises related to techniques with forehand components, backhand, volley and serve (3) provision of solution on the subject of the study by applying the basic technique exercise model of Goenrich tennis field - based play approach (4) implementation of post-test techniques in relation to forehand, backhand, volley and serve (5) analyzing the results of pre-test and post-test using statistical methods (t-test) to find out whether there is a significant influence from the use of the model.

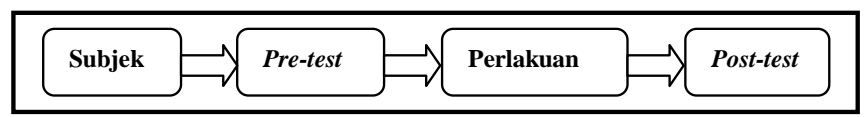

Fig. 6. Research Design in Model Effectiveness Test. (Source: prepared by Researcher)

The instrument used in the effectiveness test of this model is the Hewitt test which is an internationally recognized tennis test.

\section{RESULTS AND DISCUSSION}

The development of this model has 4 major components that will be developed, namely: (1) development of forehand base blow, consisting of 7 forms of exercise (2) development of backhand baseball, consisting of 7 forms of exercise (3) development of basic volley blow, consisting of 7 forms of exercise (4) development of basic serve blow, consisting of 7 forms of exercise.

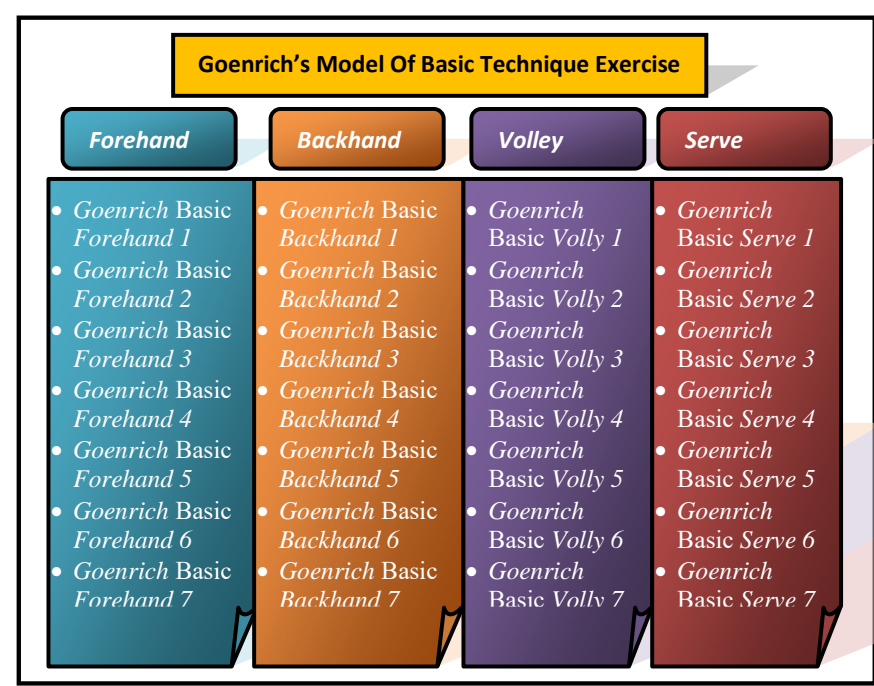

Fig. 7. Goenrich's basic technique exercise model with a play-in approach for beginners. (Source: Compiled by Researcher)

After the validation stage, evaluation and revision of the model has been developed. The next stage is the implementation of the model by testing the effectiveness of the model. The model effectiveness test was performed using a pre-experimental research design in the form of "one group control pretest-posttest design". A beginner player who is the subject of research is given a pre-test in the form of basic technique test using Hewitt test, then given solution in the form of application of Goenrich basic technique and carries out post-test using the same instrument.

Testing here is difference of forehand simultaneously between groups, to know the difference in the effect of treatment on the increase of the dependent variable of Goenrich basic exercise technique on the beginner with the approach of play before and after the treatment between groups using Independent Samples Test statistics from IBM SPSS21.0 for Windows calculation. The following results are obtained:

TABLE I. RESUlT OF INDEPENDENT SAMPLES TEST OF FOREHAND

\begin{tabular}{|c|c|c|c|c|}
\hline Forehand & Df & Mean Difference & $\boldsymbol{F}$ & Sig. \\
\hline $\begin{array}{c}\text { Equal variances } \\
\text { assumed }\end{array}$ & 76 & 5.100 & 7,728 &, 007 \\
\hline
\end{tabular}

Based on the above table it can be concluded that the significant value of Equal variances assumed (2-tailled) $0.007<0.05$. It can also be concluded that there is a difference in the effect of basic techniques of goenrich exercise and conventional training techniques on basic forehand technique skills.

Testing here is difference of Backhand simultaneously between Groups to Know Differences in the Effect of Treatment on Increased Variables Bounded Basic Goenrich exercise Techniques on Beginner Players with Approaches Before and After Intergroup Treatment Using Independent Samples Test Statistics From IBM SPSS21.0 for Windows calculations. Results are as follows: 
TABLE II. INDEPENDENT SAMPLES TEST RESULTS OF BACKHAND

\begin{tabular}{|c|c|c|c|c|}
\hline Backhand & Df & Mean Difference & $\boldsymbol{F}$ & Sig. \\
\hline Equal variances assumed & 78 & 7,375 & 1,637 &, 000 \\
\hline
\end{tabular}

Based on the above table it can be concluded that the value of significant Equal variances assumed (2-tailled) $0.000<0.05$. It can be concluded that there is a difference in the influence of basic techniques of goenrich exercise and conventional training techniques on basic engineering skills Backhand.

Testing here is difference of Volley simultaneously between groups to know the difference of treatment effect on the increase of dependent variable of Goenrich tennis exercise technique on beginner players with playing approach before and after the treatment between groups using Independent Samples Test statistics From IBM SPSS21.0 for Windows calculation. The following results are obtained:

TABLE III. INDEPENDENT SAMPLES TEST RESUltS OF VOLLEY

\begin{tabular}{|c|c|c|c|c|}
\hline Volley & Df & Mean Difference & $\boldsymbol{F}$ & Sig. \\
\hline Equal variances assumed & 78 & 6,025 & 0,085 & 0,772 \\
\hline
\end{tabular}

Based on the above table it can be concluded that the value of significant equal variances assumed is (2-tailled) $0.000<0.05$. It can also be concluded that there is a difference in the influence of basic techniques of goenrich exercise and conventional training techniques on basic engineering skills Volley.

Testing here means difference of Serve simultaneously between groups to know the difference in the effect of treatment on the increase of dependent variables of Goenrich tennis exercise technique on beginner player with playing approach before and after the treatment between groups using Independent Samples Test statistics From the calculation of IBM SPSS21.0 for Windows. The following results are obtained:

TABLE IV. RESUlts of IndePEndent SAMPLES TEST OF SERVE

\begin{tabular}{|c|c|c|c|c|}
\hline Servis & Df & Mean Difference & $\boldsymbol{F}$ & Sig. \\
\hline $\begin{array}{c}\text { Equal variances } \\
\text { assumed }\end{array}$ & 78 & 7,125 & 0,089 & 0,000 \\
\hline
\end{tabular}

Based on the above table it can be concluded that the value of sig Equal variances assumed (2-tailled) $0.000<0.05$. It can also be concluded that there is a difference in the influence of basic techniques of goenrich exercise and conventional training techniques on Servebasic engineering skills.

\section{ACKNOWLEDGMENT}

The product of this development model is made in the form of a guidebook as a reference for coaches and tennis players in the delivery of basic exercise technique materials related to the play approach. Based on the results of the model effectiveness test, it is empirically proven that the results of model products in the form of basic exercise techniques Goenrich on beginner players is very effective. This is based on the results of the basic tennis technique test using Hewitt test, showing the average value of post-test results being greater than the pre-test results. So it is stated that Goenrich's basic technique exercise model on beginner players if effectively utilized aids in improving basic tennis practice outcomes.

\section{REFERENCES}

[1] Deni Arisandi, "Pengertian Pengembangan," [https:/deniarisandi.wordpress. com/2011/07/20/pengertianpengembangan/ (diakses15 Oktober 2013).p. 10, 2013].

[2] Sugiyono, Metode Penelitian Kuantitatif, Kualitatif dan R\&D, Bandung: Alfabeta, p. 3, 2012.

[3] Universitas Negeri Malang, Pedoman Penulisan Karya Ilmiah. Edisi Kelima. Malang: Universitas Negeri Malang, p. 3, 2010.

[4] Hamid Darmadi Metode Penelitian Pendidikan, Bandung: Alfabeta, p. 6, 2011 .

[5] Kusnaka. Adimihardja, dan R. Harry Hikmat, Particapatory Research Appraisal;Pengabdian dan Pemberdayaan Masyarakat, Bandung: Humaniora Utama Press, p, 11. 2003.

[6] Stephen P. Robins, organozational Behavior: Concepts, Controversies, Applications, New York: Prentice Hall, Inc., p, 25. 1996.

[7] Averill M. Law, dan W.David Kelton, Simulation Modeling and Analysis, New York; McGraw-Hill. Inc., p, 5. 2000.

[8] Lorrie R. Gay, Geoffrey Mills, Peter W. Airasian, Educational Research: Competencies for Analysis and Applications, New York: Merrill/Pearson, p, 4. 2000.

[9] Meredith D. Gall, Joyce P. Gall, Walter R. Borg, Educational Research: An Introduction $7^{\text {th }}$ Ed., Boston, MA: A \& B Publications, p, 569. 2003.

[10] P. J. L. Thompson, Introduction To Coaching Theory., Monaco. IAAF, p, 5. 1994.

[11] Y. Hadisasmita, dan Syarifudin, A.. Ilmu Kepelatihan Dasar., Jakarta: Departemen Pendidikandan Kebudayaan, Direktorat Jendral Pendidikan Tinggi, Proyek Pendidik Tenaga Akademik., p, 23. 1996.

[12] J. Nossek,. Teori Umum Latihan.Dr. A. Eleyae, Pengalih Bahasa Lagos: Pan African Press. Ltd., p, 13. 1982.

[13] Grosser, dkk,. Latihan Fisik Olahraga. [Jakarta: Pusat pendidikan dan Penataran Bidang Penelitian dan Pengembangan KONI Pusat]., p, 2. 2001.

[14] Widiastuti, Tes dan Pengukuran Olahraga, Jakarta; Rajawali Pers., pp, 233-234, 2015.

[15] Rahmat dan Ganesha. Jadi Juara dengan Sepakbola Possesion. Jakarta: KickOff Media, p, 112. 2012.

[16] Yudha M. Saputra,. Perkembangan Motorik: Sebuah Konsep dan Implementasi. Bandung: UPI., p, 28. 2006.

[17] Meredith D. Gall, Joyce P. Gall, Walter R. Borg, Educational Research: An Introduction $7^{\text {th }}$ Ed., Boston, MA: A \& B Publications, pp, 775-776. 2003. 